\title{
WestVirginiaUniversity
}

THE RESEARCH REPOSITORY @ WVU

Graduate Theses, Dissertations, and Problem Reports

2001

\section{Green tea antioxidants inhibition of oxidation and mutation}

Paul Stout McConnell
West Virginia University

Follow this and additional works at: https://researchrepository.wvu.edu/etd

\section{Recommended Citation}

McConnell, Paul Stout, "Green tea antioxidants inhibition of oxidation and mutation" (2001). Graduate Theses, Dissertations, and Problem Reports. 1297.

https://researchrepository.wvu.edu/etd/1297

This Thesis is protected by copyright and/or related rights. It has been brought to you by the The Research Repository @ WVU with permission from the rights-holder(s). You are free to use this Thesis in any way that is permitted by the copyright and related rights legislation that applies to your use. For other uses you must obtain permission from the rights-holder(s) directly, unless additional rights are indicated by a Creative Commons license in the record and/ or on the work itself. This Thesis has been accepted for inclusion in WVU Graduate Theses, Dissertations, and Problem Reports collection by an authorized administrator of The Research Repository @ WVU. For more information, please contact researchrepository@mail.wvu.edu. 


\title{
Green Tea Antioxidants Inhibition of Oxidation and Mutation
}

\author{
Paul S. McConnell \\ Thesis submitted to the \\ College of Agriculture, Forestry and Consumer Sciences \\ At West Virginia University \\ In Partial fulfillment of the requirements \\ For the degree of \\ Master of Science \\ In \\ Genetics and Developmental Biology \\ Knox Van Dyke, Ph.D., Chair \\ Walter Kaczmarczyk, Ph.D. \\ Richard W. Russell, Ph.D. \\ Department of Genetics and Developmental Biology \\ Morgantown, West Virginia \\ 2001
}

Key Words: Green tea, antioxidants, oxidative stress, plasmid DNA 


\section{Abstract \\ Green Tea Antioxidants Inhibition of Oxidation and Mutation}

\section{Paul S. McConnell}

Green tea is a complex mixture containing several major potent antioxidants e.g., flavins and/or polyphenols. These antioxidants in green tea may react directly or indirectly with strong oxidizers e.g. peroxynitrite or its constituents (superoxide or nitric oxide). Green tea antioxidants can destroy the oxidants. Based on a simple chemical interaction of peroxynitrite (OONO-) and luminol, blue light is produced upon oxidation. It was shown that green tea and constituents have light inhibitory capabilities. In order to show the possible beneficial effects of green tea with DNA, plasmids were chosen to determine whether or not green tea was also capable of preventing oxidative based damage (mutations). It can be deduced that there are multiple levels of antioxidative protection. First, antioxidants can destroy the pieces of peroxynitrite $\left(\cdot \mathrm{O}_{2}\right.$ and $\left.\bullet \mathrm{NO}\right)$, protect from peroxynitrite itself, or protect from the damage caused to DNA by peroxynitrite. 


\section{Dedication:}

I would like to dedicate this thesis to the memory of my parents. Without them I would not be here, nor would I have the determination. 


\section{Acknowledgements:}

I would first like to most sincerely acknowledge my mentor, advisor, and stand in father figure dating back to when I began my research with him in the Fall of 1998. You were always very honest and up-front with me when I needed counsel, even though at times you were telling me not necessarily what I wanted to hear but what I needed to hear. Thank you Dr. Van Dyke for making sure that I stayed the course and being my guide along the way.

I would also like to acknowledge Dr. Kaczmarczyk for being co-advisor to me and helping me to survive the department. Our many long conversations and the advice you have giving me over the years will not be forgotten. I would also like to acknowledge Dr. Russell for serving on my committee, thank you for being there. There have been many times throughout this ordeal that finances were a burden and I have many people to thank for helping to lighten the load for me. Of course, KVD would not have let me starve and was always willing to help. Thank you Dr. Stitzel for picking up the slack for me when all of my resources had been exhausted. And to Dr. Smart and for all whom I taught for at the Chemistry Department, thank you for giving me a job in your department, I hope I didn't let you down. I would like to thank Chris Van Dyke for his many countless hours of assistance. Whether it was putting together figures or writing essays, your unending vastness of knowledge and insight helped me to make it through and also corrected some of my computer illiteracy's. To my friends in the departments of which I was a part of in my tenure (all four!). To Jeff Holstein and Dennis Coss, you know my pain and I can empathize with you as well. Tuesdays at Chicken Bones after seminar was therapeutic. To Bonnie Hulley, thanks for helping me to navigate the thesis submission process. To J.R. Taylor, thanks for keeping me in line in the labs and making sure that noone was hurt to badly under my watch. To Mike Taylor for being there for me to vent and also make me feel better about being such a procrastinator. I hope we go fishing many more times in the future, and if all goes well we'll be able to sip on cocktails with the little umbrellas somewhere in the Caribbean like we talked about. To Meredith McCracken and Tripp Griffin, thanks for helping me out along the way. To Dr. Reasor, thank you for your lessons on scientific matters and those learned on the racquetball court. To Meir Sacks, thanks for your counsel on how to survive, in more ways than one, and don't forget me when you and the "Old Man" strike it rich. I may be coming to you for a job someday.

Lastly, to my family and friends. Thank you for your support along the way. You give me strength in more ways than you can imagine. 


\section{Table of Contents}

Abstract

Page

Abstract

Dedication

ii

Acknowledgements

iii

Table of Contents

iv

List of Figures and Tables

V

Preamble

vii

References for Preamble

ix

Abstract for Study 1

1

Introduction for Study 1

Methods for Study 1

Results for Study 1

Discussion for Study 1

References for Study 1

Abstract for Study 2

Introduction for Study 2

Methods for Study 2

Results for Study 2

Discussion for Study2

References for Study 2 


\section{List of Figures and Tables}

\section{Study 1}

\section{Page}

$\begin{array}{ll}\text { Figure } 1 & 14\end{array}$

$\begin{array}{ll}\text { Figure2 } & 15\end{array}$

$\begin{array}{ll}\text { Figure } 3 & 16\end{array}$

$\begin{array}{ll}\text { Figure } 4 & 17\end{array}$

$\begin{array}{lr}\text { Figure } 5 & 18\end{array}$

$\begin{array}{ll}\text { Figure } 6 & 19\end{array}$

$\begin{array}{ll}\text { Figure } 7 & 20\end{array}$

$\begin{array}{ll}\text { Figure } 8 & 21\end{array}$

$\begin{array}{ll}\text { Table } 1 & 22\end{array}$

\section{Study 2}

$\begin{array}{ll}\text { Figure } 1 & 30\end{array}$

$\begin{array}{ll}\text { Figure } 2 & 30\end{array}$

$\begin{array}{ll}\text { Figure } 3 & 31\end{array}$

$\begin{array}{ll}\text { Figure } 4 & 32\end{array}$

$\begin{array}{ll}\text { Table } 1 & 33\end{array}$ 


\section{Preamble}

Oxygen is essential for life. It is used by the body in metabolic reactions to oxidize or burn foodstuffs to supply energy. However, a variety of oxidative species, free radicals (contain an unpaired electron), and excited state substances are formed. This would include singlet oxygen (excited states epsilon $\mathrm{E}$ and delta $\Delta)$, superoxide $\left(\cdot \mathrm{OO}^{-}\right)$, hydrogen peroxide $\left(\mathrm{H}_{2} \mathrm{O}_{2}\right)$, hydroxyl radical $(\bullet \mathrm{OH})$ and certain metabolites, peroxynitrite $\left(\mathrm{OONO}^{-}\right)$and hypochlorite $\left(\mathrm{OCl}^{-}\right)$. However, there are likely others. In fact, it has been estimated that for every $10^{12}$ oxygen molecules that enter a cell, 1/100 damages protein and 1/200 damages RNA or DNA (1).

However, there are known downsides to oxygen. When the production of oxidants exceed the amounts of antioxidants, oxidative stress occurs and the damage previously mentioned may occur (2). Therefore, how do we prevent oxidative stress from occurring? First, we must understand the two opposing forces that control the Yin and Yang of the situation. What constitutes an oxidant or an antioxidant (reductant)? An oxidant is any substance which loses an electron or hydrogen or gains an oxygen. Therefore, an antioxidant is just the opposite, a substance that gains an electron or hydrogen or loses oxygen. If the oxidant and antioxidant are 
balanced, oxidative homeostasis is produced. However, oxidative stress occurs when the oxidant to antioxidant ratio exceeds one.

The body contains within itself several naturally occurring antioxidants to combat the damaging environment which can be created by oxidative stress. There are enzymes which are able to destroy oxidants directly or can be readily oxidized, such as glutathione peroxidase and superoxide dismutase. Also, blood contains a powerful antioxidant in uric acid which can be oxidized into various metabolites. With the increasing awareness of the importance to supplement these naturally occurring antioxidants, the search is on for substances which can increase antioxidant load. 


\section{References for Preamble:}

1. Ohshima H, Yoshie Y, Auriol S and Gilbert I. Antioxidant and Prooxidant action of flavonoids: Effects on DNA damage induced by nitric oxide, peroxynitrite, and nitrosyl anion. Free Radical. Biol Med 1998; 25 (9): 1057-65.

2. Salgo MG, Stone K, Squadrito GL, Battista JR, and Pryor WA. Peroxynitrite causes nicks in plasmid pBR322. Biochem Biophys Res Comm 1995; 210: 1025-30. 


\title{
Study 1
}

\section{Green tea extract and its polyphenols markedly inhibit luminol- dependent chemiluminescence activated by peroxynitrite or SIN-1}

\begin{abstract}
This study is based on a simple chemical interaction of peroxynitrite (OONO-) and luminol, which produces blue light upon oxidation. Because peroxynitrite has a half-life of less than 1s, a drug known as SIN-1 is used as a peroxynitrite generator. In addition, peroxynitrite itself was used directly with a fast injection-mixing system to ascertain whether there are differences between it and the peroxynitrite-generating system (SIN-1) which mimics the natural production of (OONO-). Peroxynitrite is a potent oxidizing compound (1000 times more active than equidose hydrogen peroxide) and it can oxidize carbohydrates, lipids, proteins, and nucleic acids. Upon stimulation by inflammation and/or infection, macrophages and neutrophils can be activated to produce large amounts of peroxynitrite. We are interested in simple chemicals that are non-toxic that could inhibit or destroy peroxynitrite, which might otherwise cause inappropriate damage to blood and tissues. Green tea is a complex mixture containing several potent major antioxidant constituents, e.g. flavins and/or polyphenols. The constituents in green tea may react directly or indirectly with peroxynitrite or its constituents through the process of antioxidation to inhibit light. Alternatively, compounds could produce superoxide which, when reacted with nitric oxide, could produce more peroxynitrite and hence more light with luminol. Therefore, as the tea or antioxidants from tea are diluted, while the peroxynitrite or its precursors are kept at a constant concentration, one can
\end{abstract}


observe unusual behavior regarding light emission. Initially, at high doses of tea or antioxidant, one observes clear inhibition of the light generated form the reaction of peroxynitrite and luminol. However, at dilute concentrations of antioxidants, one can often observe stimulation of light. Possible reasons for these observations are discussed.

\section{Introduction}

Apart from water, tea is probably the most popular beverage world-wide. Its healthpromoting benefits have been observed and used by the Chinese and Indians for thousands of years. Green tea and black tea are derived from the same plant (Camellia sinensis). The difference between the two teas lies mainly in the processing. Green tea is steamed lightly, which inactivates the phenol oxidases responsible for the oxidation of the polyphenols, leaving more of these compounds in an unoxidized state (1). Therefore, because the polyphenols are left in the reduced or unoxidized state, they could act aggressively as antioxidants against strong oxidizing substances like peroxynitrite $(\mathrm{P})$ or even hypochlorite $(\mathrm{H})$, which is produced in the presence of hydrogen peroxide, chloride ion, via the enzyme, myeloperoxidase. When these oxidizing substances are inappropriately spilled outside the phagocytic vacuole, they can damage surrounding tissue, causing oxidative-based inflammatory diseases, e.g. Alzheimer's disease, Parkinson's disease, amyotrophic lateral sclerosis, stroke, arthritis, anoxia, lung fibrosis, chronic obstructive pulmonary disease, atherosclerosis, and many other diseases (2). Therefore, having easily oxidizable substrates such as polyphenols in tea may act in this manner and protect against bacterial and/or viral activity and act against cancer and mutation (1). 
The polyphenols (catechins) are probably the most important antioxidants extracted from green tea(3). The major polyphenols from green tea are listed in Fig. 1. It is thought that the most active antioxidant is epigallocatechin gallate, which is the gallate ester of epigallocatechin. We decided to test the antioxidant effect of green tea and some of its constituents against luminol-dependent chemiluminescence activated by peroxynitrite (4). Because peroxynitrite oxidizes luminol to an intermediate that produces light, antioxidants will inhibit this blue light by interfering with the oxidation of the luminol. In addition, we used SIN-1, which produces both superoxide and nitric oxide, which combine to produce peroxynitrite (Fig. 2). The antioxidants in green tea should produce inhibitory activity against the production of light in a similar manner regardless of whether peroxynitrite comes directly or indirectly from SIN-1. However, the components of peroxynitrite, i.e. superoxide and nitric oxide, are produced by SIN-1 and their processing/production or assemblage can be inhibited or interfered with in a manner not available with peroxynitrite alone.

The purpose of this study is to measure the antioxidant activity of green tea extract and some of its prominent polyphenols. This is accomplished by using the antioxidants to oppose the oxidation of luminol by peroxynitrite and thereby inhibit the production of blue light.

\section{Methods}

\section{Reagents}

Three sydnonimine congeners (Fig.3) are known to produce both nitric oxide and superoxide and then combine to produce peroxynitrite (OONO-). We chose SIN-1 (lindsidomine) rather than C89-4144 or C87-4095 because it was the most efficient in 
rate of reaction, although for total light production C89-4144 was somewhat better (Fig.4). SIN-1 formed the basis of our continuing experiments (5) and all sydnonimines were obtained from Dr. Karl Schönafinger, Casella AG, Hanauer Landstrasse 526-6000, Frankfurt am Main 61, Frankfurt, Germany. SIN-1 produces peroxynitrite (6) at a rate of about $1 \% /$ min (based on the total amount of compound). Accordingly, the work illustrated in Fig.5 was accomplished using SIN-1 (Upstate Biotechnology, Lake Placid, NY) as the source of peroxynitrite or peroxynitrite (Fig.6) directly. SIN-1 was dissolved in $0.1 \mathrm{~mol} / \mathrm{L}$ PBS buffer $(\mathrm{pH} 7.4)$ at a concentration of $15 \mathrm{mg} / 5 \mathrm{~mL}$. It was kept on ice and maintained its activity for several hours of the experiment. Peroxynitrite (approx. 50 $\mathrm{mmol} / \mathrm{L}$ ) was diluted $1 / 1000$ with water. The original solution was supplied in $0.3 \mathrm{~mol} / \mathrm{L}$ $\mathrm{NaOH}$, and this stabilizes the compound. Once diluted, it must be kept on ice and used quickly, especially after dilution. The diluted basic OONO- is then rapidly injected into the PBS buffer at $\mathrm{pH}=7.4$. Under these neutralizing conditions the half-life of OONO- is less than $1 \mathrm{~s}$ (Fig.6). Rapid injecting and mixing are crucial in this situation, unlike the slower reaction with SIN-1. However, the slower reaction with SIN-1 gives an opportunity to dissect the reaction into its component parts, since rapid reaction and injection/mixing are not so crucial.

The luminol was obtained from Sigma, St. Louis, MO. It was dissolved first in $1 \mathrm{ml}$ DMSO and then diluted to produce a stock solution $\left(10^{-4} \mathrm{~mol} / \mathrm{L}\right)$ in $0.1 \mathrm{~mol} / \mathrm{L}$ phosphate buffered saline at $\mathrm{pH}$ 7.4.

Green tea powdered extract was purchased from Pharmanex, Simi Valley, CA. 250 $\mathrm{mg}$ was dissolved in $10 \mathrm{~mL}$ of phosphate buffered saline (PBS) at $\mathrm{pH}$ at 7.4 and used as a 
stock solution (dilutions are made using PBS, and antioxidant samples from this original stock solution were diluted every 10 -fold from one to 1 million, i.e., six samples).

\section{Chemiluminescence assay}

$100 u \mathrm{~L}$ of luminol solution $(0.6 \mathrm{mmol} / \mathrm{L}$ final concentration, $100 u \mathrm{~L}$ of dilutions of green tea in $0.1 \mathrm{~mol} / \mathrm{L}$ PBS buffer $(\mathrm{pH}=7.4)$ and $200 u \mathrm{~L}$ buffer alone and $100 u \mathrm{~L}$ of the solution of SIN-1 (5.8 mmol/L final concentration) or derivative were pipetted into a 3 $\mathrm{mL}$ round-bottomed luminometer tube, resulting in a total volume of $500 u \mathrm{~L}$. A control solution was also used to provide a reference to the light stimulation produced by the combination of SIN-1 and luminol. The final volume of this solution consisted of $100 u \mathrm{~L}$ of luminol, $300 u \mathrm{~L}$ of buffer and $100 u \mathrm{~L}$ of SIN-1. SIN-1 and derivatives were kept on ice prior to pipetting and were the last reagents added, because of their instability at room temperature. The majority of strong antioxidants are polyphenols (see Fig. 1).

The luminometer tube was placed in a Berthold Luminometer, model LB9505C, sixchannel luminometer with the temperature control set at $37^{\circ} \mathrm{C}$ and the light reaction was measured for 20 min. Peroxynitrite, which reacts directly with luminol, was injected using an essentially pressure semi-independent injection device, which injects $1 / 50$ of the total volume (2500 um) of a gas-tight syringe, made by the Hamilton Co. (Patent No. 3161323 ), Whittier, CA, to produce a blue light at $425 \mathrm{~nm}$, which corresponds to the most sensitive detection range of the photomultipliers for this luminometer. The injection device was linked to a gas-tight $2500 u \mathrm{~L}$ syringe with a fixed needle of $5.2 \mathrm{~cm}$. This length of needle was necessary to penetrate the septum of the ports of the six-channel Berthold Luminometer and to extend into the tube far enough to produce reproducible 
mixing; this precaution was necessary because of the short half-life of peroxynitrite. In Fig. 6, repetitive injections of peroxynitrite are shown giving the light generated over a 1 min period, which was acquired, plotted and integrated with an IBM clone computer running KINB software. In the case of SIN-1, the ingredients were mixed prior to assay, with SIN-1 added last. The assay was reported as counts per minute integrated over the 20 min period. We measured the area under the light curve (Auc) because it reproduces better and is generally more meaningful than peak height. AUC measurements are accomplished by utilizing a KINB program supplied with the instrument (Berthold). This program utilizes trapezoidal approximation as the method of measurement for AUC.

\section{Statistics}

Chemiluminescence was integrated over the initial 20 min of each reaction with SIN-1 and $1 \mathrm{~min}$ for the peroxynitrite. Reactions were repeated in separate experiments a minimum of three times. All bar graphs depict averages and the associated error bars represent standard deviations. Significance level is set at $\mathrm{pH}<0.05$ and is calculated from the appropriate Student's $t$-test where appropriate. Blanks were run without SIN-1 or peroxynitrite and produced a minimal light signal that was ignored in assays.

\section{Results}

Fig. 1 shows the structures of the various constituents found in the green tea powdered extract that we assayed. Tests were run to determine the inhibitory effects of the individual constituents on the light-producing properties found in the combination of SIN-1/peroxynitrite and luminol. These data form the basis of the results which follow.

Fig. 2 shows the probable mechanism by which SIN-1 hydrolyses at $\mathrm{pH}=7.4$ and produces the peroxynitrite anion. This production of peroxynitrite is the result of base 
catalysis and ring-opening of the five-membered sydnonimine and its reaction with dissolved oxygen, thereby reducing the oxygen and producing superoxide anion and a ring-opened compound which, upon rearrangement, releases nitric oxide gas (a free radical). The two free radicals combine and produce the peroxynitrite anion and the spent products. It is the peroxynitrite that reacts with the luminol, producing blue light which is readily detectable via the individual photomultipliers of the luminometer. Fig. 3 shows the structures of various sydnonimines that hydrolyse to produce peroxynitrite, including C89-4144, C87-4095 and SIN-1. Fig. 4 shows the three SIN-1 congeners as they react with luminol to produce blue light.

Fig. 5 illustrates repeated reactions of luminol with $\mathrm{SIN}-1$ at $\mathrm{pH}=7.4$. Multiple reactions under similar conditions with peroxynitrite are shown in Fig. 6. The reactions appear quite different, since it takes time to generate light via SIN-1, whereas peroxynitrite reacts and decays in a fraction of a second.

Fig. 7 shows the inhibitory effects of each dilution of green tea extract added to the SIN-1/luminol-producing combination. The green tea extract, consisting mostly of polyphenols, produces inhibition of luminol-based light at full strength and up to 10,000 fold dilution, and at $0.005 \mathrm{mg}$ the inhibition is about $50 \%$. Further dilution appears to produce a slight increase in inhibition.

Fig. 8 demonstrates a similar inhibition with peroxynitrite and luminol, except that the $50 \%$ inhibition point occurs at 1000 -fold dosage of green tea extract and, as the 10 -fold dilution continues inhibition, increases to $75 \%$ or more as a kind of a biphasic response.

In Table 1, we see the inhibitory effects of (-)epicatechin on SIN-1 activated luminol luminescence. A 1:10,000 dilution at $0.45 u \mathrm{~mol} / \mathrm{L}$ produces an approximately $10 \%$ 
inhibition. In the next portion of Table 1, the same inhibitory potency can be seen with peroxynitrite, but at a 10,000 -100,000 dilution, $75-95 \%$ inhibition of light can still be seen.

The inhibitory effects of racemic catechin can be observed on SIN-1 activated luminol light. Table 1 shows that at 1:1000 dilution of catechin there is a 50\% inhibition of light, but 10 -fold dilutions after that display little inhibition. A similar pattern is seen with peroxynitrite-based light, but the $50 \%$ inhibitory effect is not seen until the $1: 10,000$ dilution. At 1:100,000, 50\% inhibition is still seen.

The inhibitory effects on (-) epigallocatechin gallate is seen on SIN-1 activated luminol light in Table 1; it inhibits at full strength and at 1:10 dilution at 100\%, but further dilution actually stimulates production of light. The same pattern of behavior cannot be seen with this compound using peroxynitrite as the activator of luminol in the table.

(-)Epicatechin gallate displayed solid inhibition (60\%) at 1:1000 dilution when SIN-1 was used as the activator of luminol light (Table 1) but when peroxynitrite was used as the activator of luminol light 100\% inhibition of light was seen at 1:10 dilution and about $25 \%$ inhibition of light production was seen in consecutive 10 fold dilutions after that point (Table 1).

\section{Discussion}

Peroxynitrite can be formed from superoxide and nitric oxide (7). It can also be produced from the hydrolysis of certain drugs called sydnonimines. The sydnonimine most widely 
used is linsidomine (SIN-1), because this is a source of both substances that produce peroxynitrite (5).

At physiological $\mathrm{pH}$, peroxynitrite reacts with luminol, producing an initial excited state which relaxes to ground state with emission of blue light (Fig.6). The reaction occurs because luminol is oxidized by peroxynitrite (8). Antioxidants added to the aforementioned reaction mixture will generally interfere with oxidation of luminol by directly reacting with the peroxynitrite. SIN-1 was chosen as the source of peroxynitrite because it produces ample light and exhibits the earliest peak (Fig.4). In addition, because the components of SIN-1 are produced by this drug, it can be used to generate peroxynitrite at a much slower rate, which allows us the chance to inhibit the individual components of peroxynitrite, in a similar way to that in which the body might inhibit the actual physiological generation of peroxynitrite.

Extract of green tea inhibits luminol light production by reacting with peroxynitrite from SIN-1, as seen in Fig. 7. It also inhibits luminol light production from peroxynitrite (Fig.8). Even 1:10,000 dilutions of the tea produce a measurable inhibition. Comparatively, the two sets of data (shown in Figs.7 and 8) should be very similar. The reasons for the discrepancies found can only be theorized. One possible explanation concerns the nature of SIN-1 as compared to the pure peroxynitrite form. SIN-1 degrades over time into peroxynitrite by the formation of superoxide and nitric oxide. Fig. 8 indicates that luminol oxidation via SIN-1 became less effective with increasing dilutions of tea extract, as expected. However, Fig. 7 shows that luminol oxidation from peroxynitrite was less effective at the third dilution, but that further dilutions again produced inhibitory behavior. It is difficult to explain this phenomenon. One possible 
explanation takes into account the stimulatory capabilities of some non-phenolic antioxidants and/or phenols (9). As the structures in Fig. 1 indicate, green tea constituents contain a number of polyphenols and there are antioxidants that are not polyphenols. It could be theorized that there is stimulation when inhibition is unmasked by some compounds being formed in the tubes containing peroxynitrite rather than SIN-1.

It appears that oxidants play a major role in ridding the body of unwanted substances, including bacteria, parasites, and viruses. Oxidants such as peroxynitrite, hypochlorite/myeloperoxidase and superoxide/hydrogen peroxide/ferrous ion can produce high toxicity. When properly confined and compartmentalized, these oxidants play a role in attacking invaders and maintaining health. Sometimes these reactions can get out of control and produce severe inflammation, which can become chronic, e.g. in arthritis. Therefore, the chemical reactions involved in colitis, meningitis or multiple organ failure are continually produced in high levels during the actual disease state. In all these examples of chronic inflammation, toxic oxidants are produced which play a major role in producing the signs of inflammation. Therefore, it makes sense that chemicals that could prevent the oxidants from getting out of control would be antioxidants. There are two well-known types of natural antioxidants: water soluble, e.g. vitamin C; and fat soluble, e.g. vitamin E. In addition, the polyphenolic constituents of green tea could be important to spare the antioxidants that are already in the body. Whether a substance acts as an antioxidant or an oxidant depends on where the substance in question lies on an oxidant-reductant scale. Vitamin $\mathrm{C}$ can be an antioxidant or an oxidant, depending on where it lies on the redox scale relative to other substances. 
Table 1 shows the effects of various green tea polyphenols on SIN-1 and peroxynitrite activated light, respectively. In comparison to the other catechins, the (-) epicatechin constituent from green tea demonstrated the overall greatest amount of inhibition of peroxynitrite- or SIN-1 based light. The exact chemical reasons are unclear, but may be related to the redox potential of the phenol vs. peroxynitrite as an oxidant. The second most active antioxidant was (-) epicatechin gallate, which is a gallic ester of epicatechin. The reactions of (-) epicatechin gallate against SIN-1 or peroxynitrite are shown in Table 1. Both components are active in over 1:1000-fold dilution at about 50\% inhibition.

Racemic catechin is very active against SIN-1 or peroxynitrite, as seen in Table 1. Indeed, 1000 -fold dilution from original stock at $0.45 \mathrm{mmol} / \mathrm{L}$ produces about $50 \%$ inhibition from both oxidants used previously. This inhibition for peroxynitrite was maintained up to 1:10,000 dilution, which was a very impressive demonstration.

Finally, epigallocatechin gallate showed stimulation of light, rather than inhibition, from SIN-1 or peroxynitrite (see Table 1) at the 1:100 dilution from stock at $0.45 \mathrm{mmol} / \mathrm{L}$. Clearly, it was the weakest antioxidant tested. One of its phenols has three $\mathrm{OH}$ groups and gallic acid has three phenolic $\mathrm{OH}$ groups. This combination might affect access toward oxidants. Certainly, higher doses of the drug might still be effective. Stimulation of light by phenols or metabolites is a well-studied phenomenon and a recent study has suggested a chemical logic for this (9).

It should be noted that high dose (-) epicatechin and (-) epigallocatechin gallate changed color when SIN-1 was added to the solution. At the end of the $20 \mathrm{~min}$. incubation in the luminometer, the solutions of the two compounds turned a distinct yellow. This color change may have occurred due to chemical attack by peroxynitrite. A 
possible explanation for this phenomenon may be that the constituents experienced nitration and/or hydroxylation (10). A metabolite could produce an inhibition of light or a stimulation, depending on its interaction with excited state luminol.

\section{References:}

1. Mitscher LA, Jung M, Shankel D, Dou J, Steele L, Pillai S. Chemoprotection: a review of the potential therapeutic antioxidant properties of green tea (Camillia sinensis) and certain of its constituents. Med Res Rev 1997;17 (4):327-65.

2.Szabo C. Physiological and pathophysiological roles of nitric oxide in the central nervous system. Brain Res Bull 1996;41:131-41.

3.Gutman RL, Ryu BH. Rediscovering tea: an exploration of the scientific literature. Herbal Grams 1996;37:34-49.

4. Van Dyke K, Sacks M, Qazi N. Acetaminophen (Tylenol®) and related phenols act as antioxidants against peroxynitrite-based luminol-dependent chemiluminescence: possible linkage to antipyretic and analgesic activity. J Biolumin Chemilumin 1998; 13: 339-348. 5. Just M, SchGnafinger K. Antithrombic properties of a novel syndnonimine derivative. J Cardiovasc Pharmacol 1991; Suppl 3:5121-6.

6. Crow JP, Ischiropoulos H. Detection of quantitation of nitrotyrosine resides in proteins: in vivo marker for peroxynitrite. Methods Enzymol 1996;269:185-94. 7.Murphy MP, Packer MA, Scarlett JL, Martin SW. Peroxynitrite: a biologically significant oxidant. Gen Pharmaco. 1988;31:179-86.

8. Radi R, Cosgrove TP, Beckman JS. Peroxynitrite-induced luminol chemiluminescence. Biochem J 1993;290:51-7. 
9. Diaz AN, Sanchez G, Garcia JAG. Phenol derivatives as enhancers and inhibitors of luminol- $\mathrm{H}_{2} \mathrm{O}_{2}$-horseradish peroxidase chemiluminescence. J Biolumin Chemilum $1998 ; 13$ 75-84.

10. Ramezanian MS, Padmaja S, Koppenol WH. Nitration and hydroxylation of phenolic compounds by peroxynitrite. Methods Enzymol 1996;269:195-201. 
Figure 1

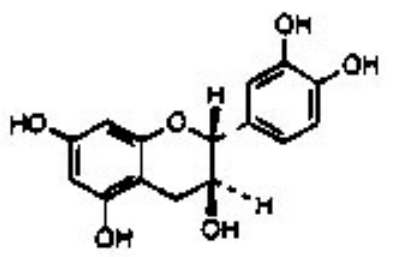

(+) Cuschin<smiles>Oc1cc(O)c2c(c1)O[C@H](c1cc(O)c(O)c(O)c1)[C@@H](O)C2</smiles>

(t) Gallocetechin

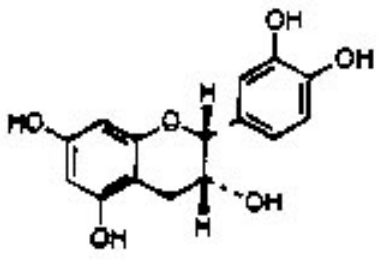

(-) Eplominging<smiles>Oc1cc(O)c2c(c1)O[C@H](c1cc(O)c(O)c(O)c1)[C@H](O)C2</smiles>

(-) Epigallocatechin

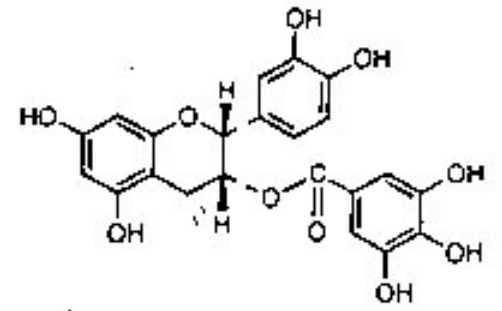

(-) Epicatechin gallate<smiles></smiles>

(-) Epigallocatechin gallate<smiles>O=C(O[C@H]1Cc2c(O)cc(O)cc2O[C@]1(O)c1cc(O)c(O)c(O)c1)c1cc(O)c(O)c(O)c1</smiles>

(+) Catechin gallate 


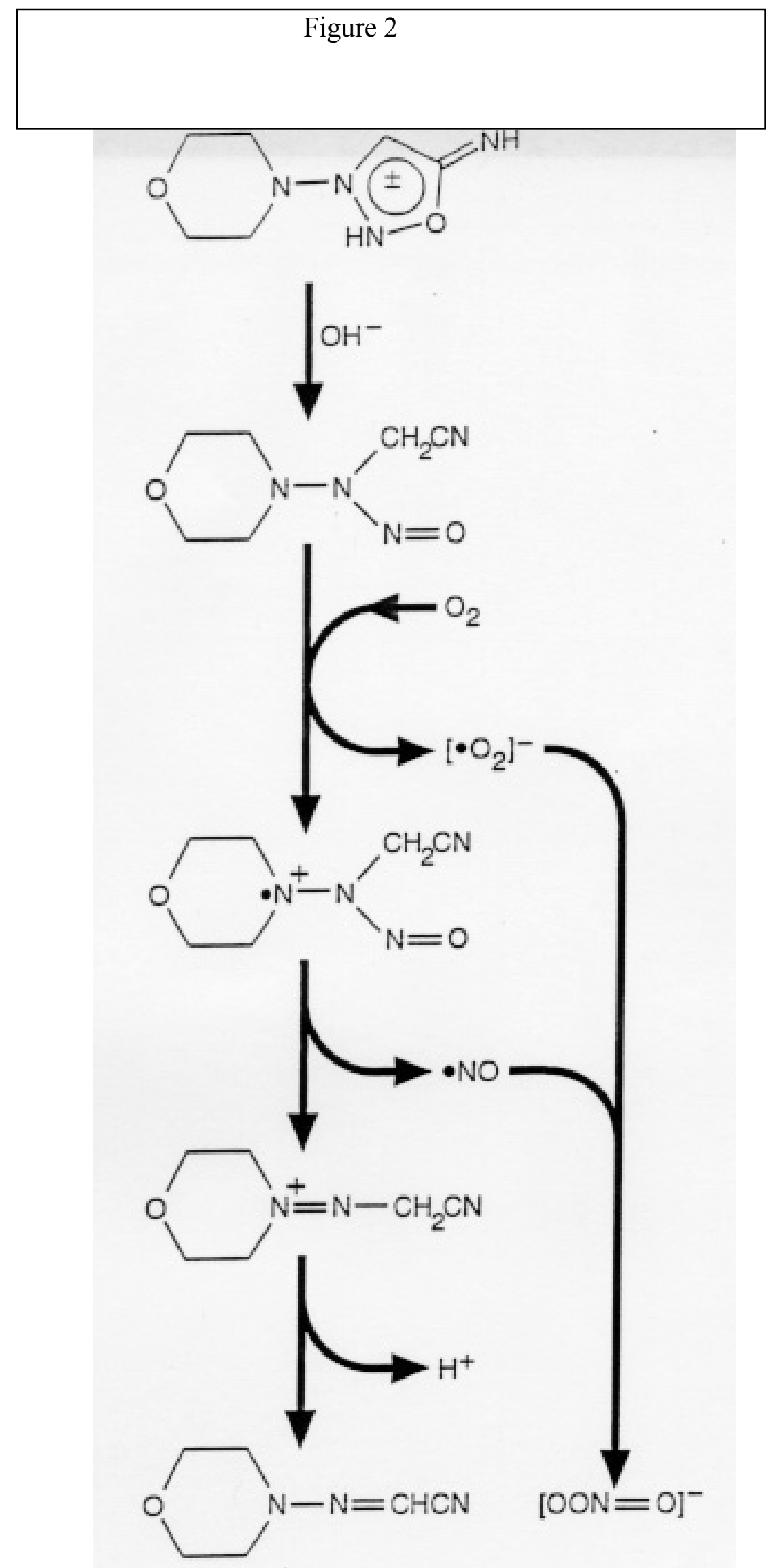


Figure 3

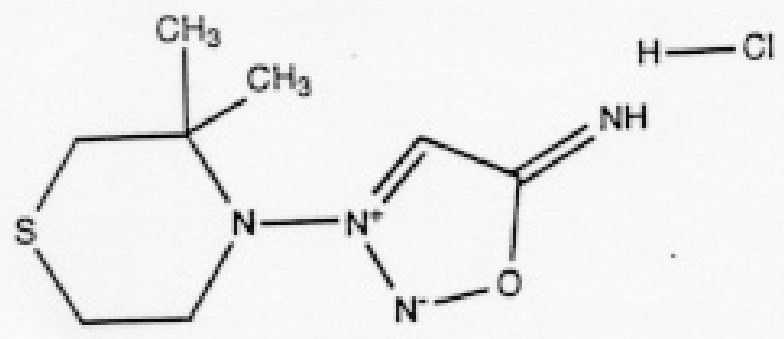

C89-4144

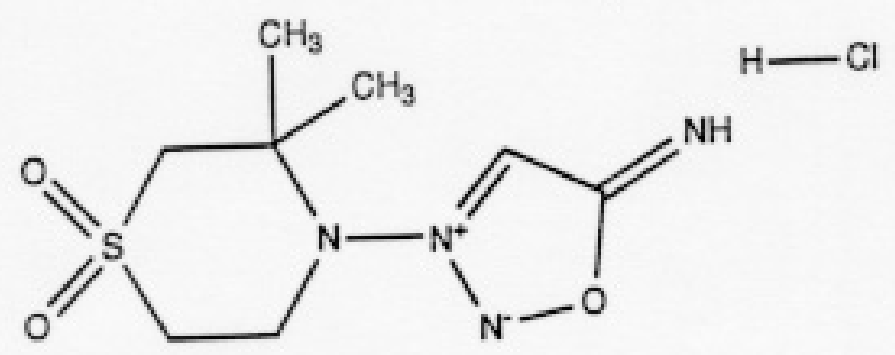

C87-4095

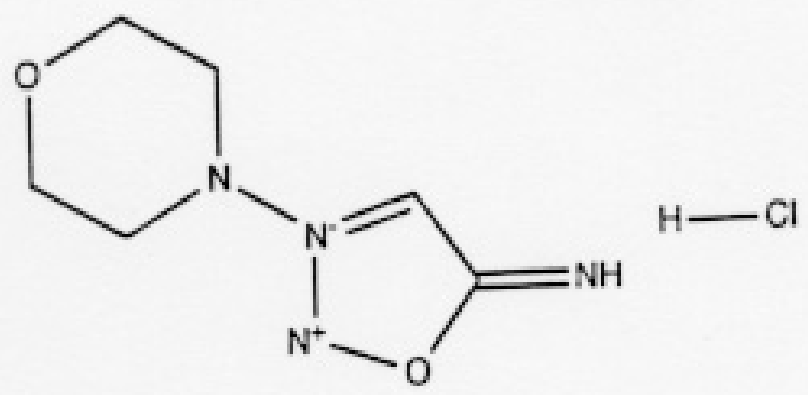

SIN 1 Substrate

(Linsidomine) 
Figure 4

SYD-2 converted

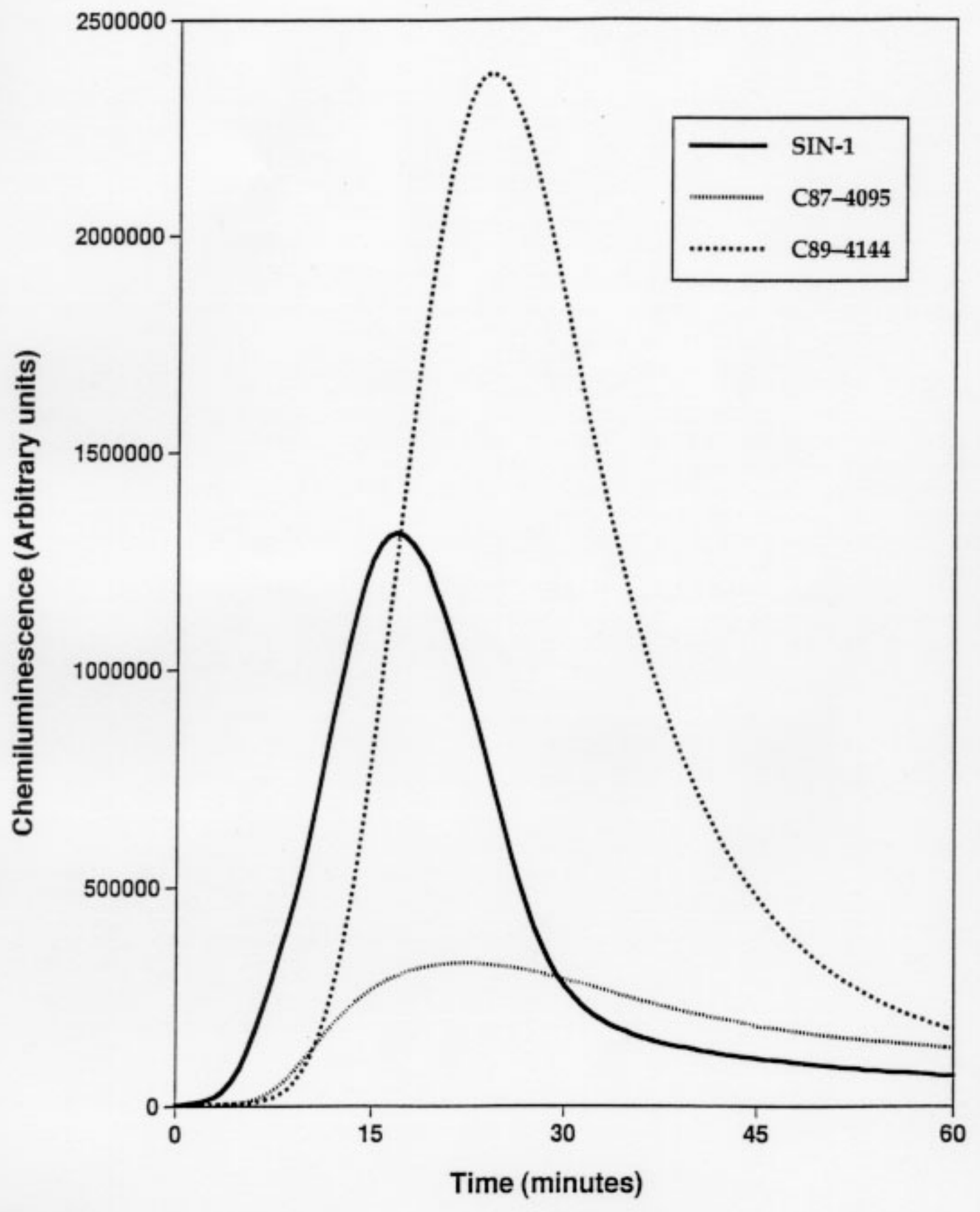


Figure 5

Luminol-Dependent Chemluminescence of SIN-1

Averaged Over Six Trails

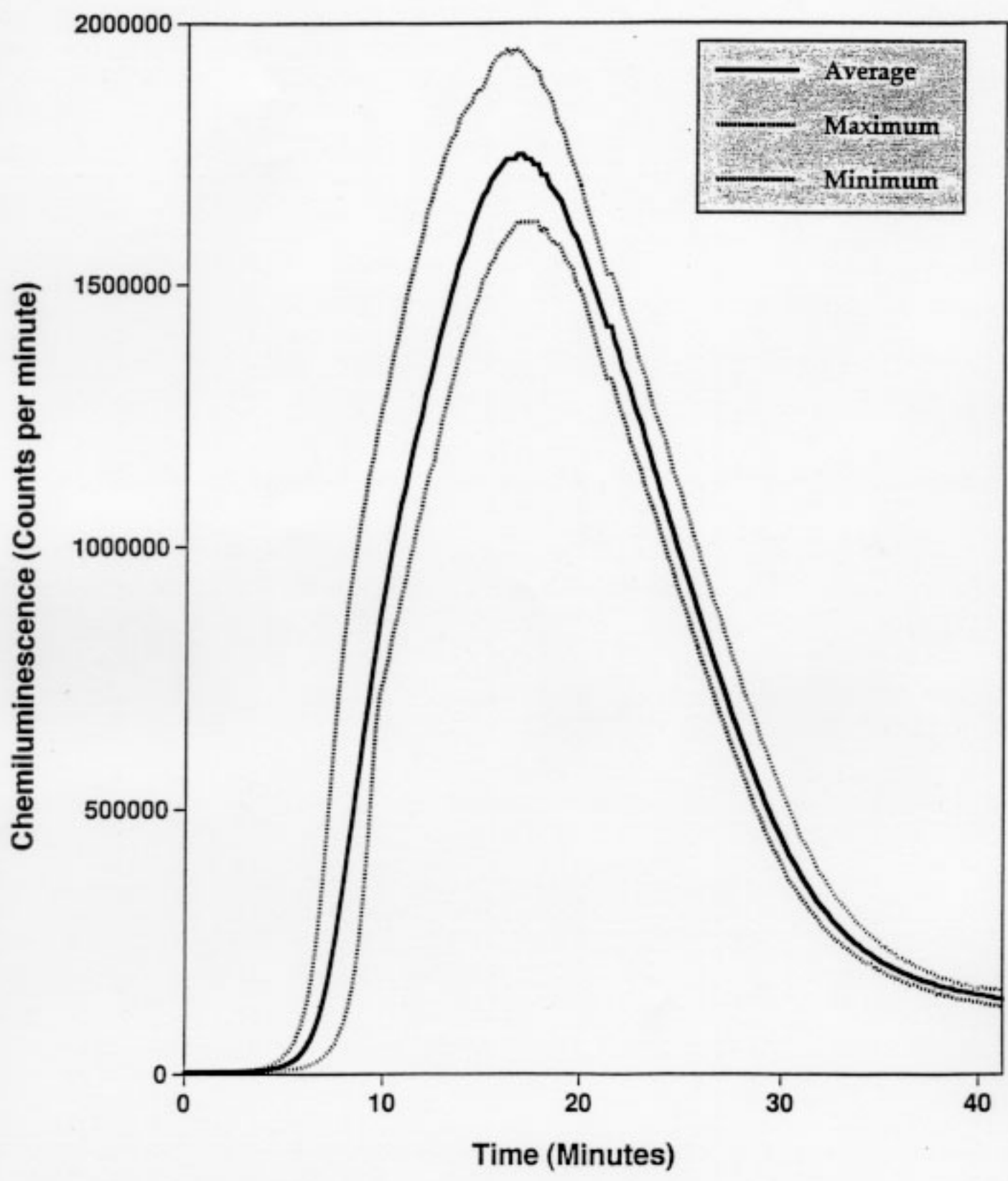


Figure 6

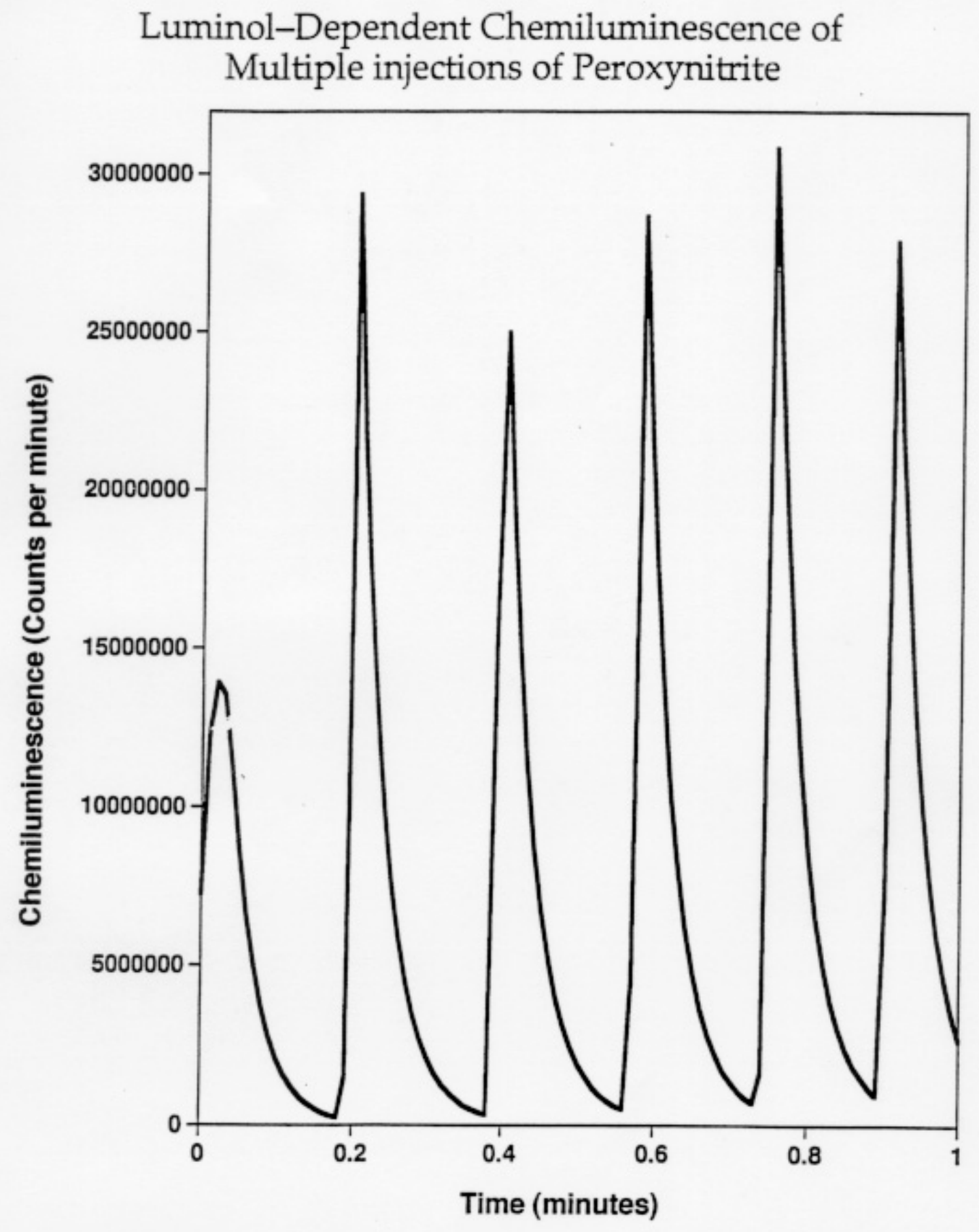


Figure 7

\section{Inhibitory Effects of Green Tea on $\mathrm{SIN}-1$}

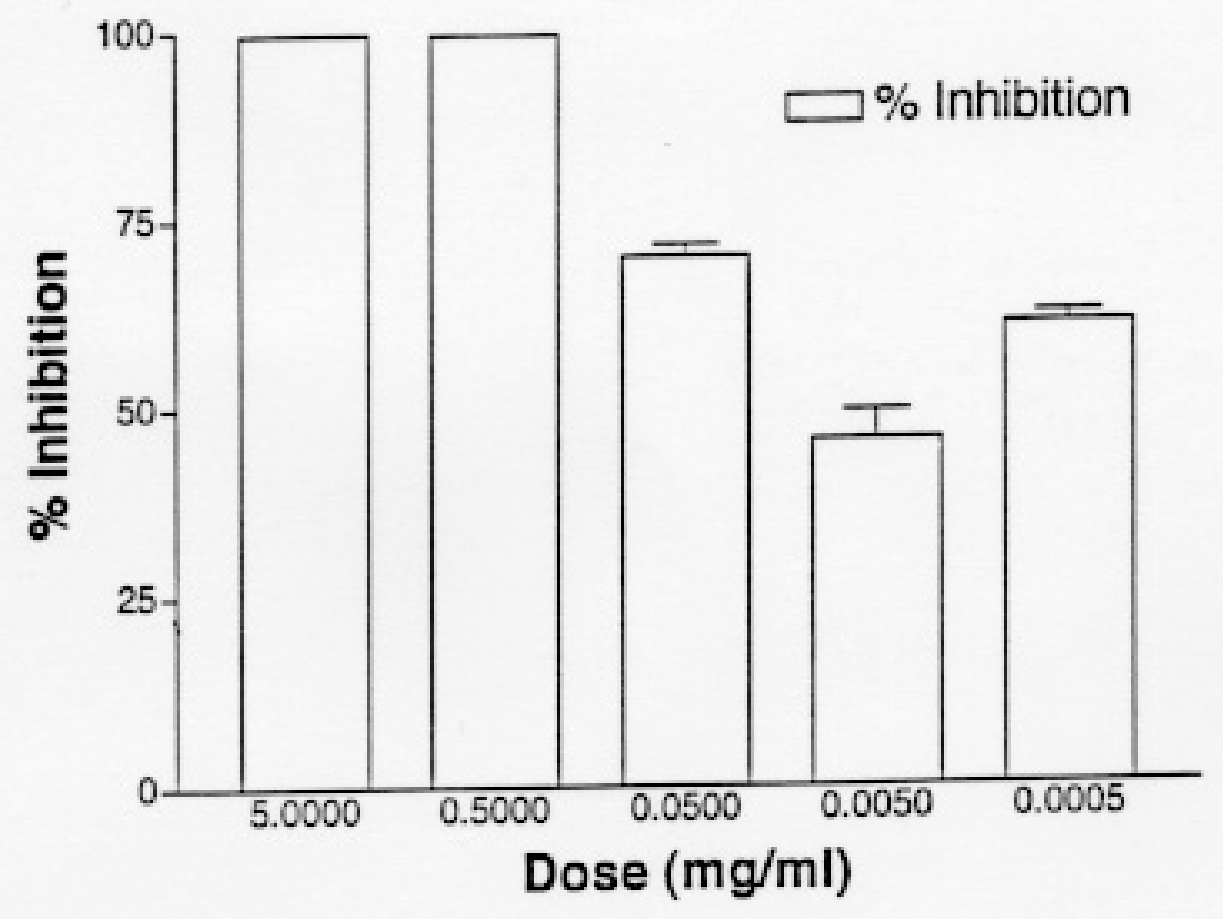


Figure 8

\section{Lipton ${ }^{\circledR}$ Green Tea Inhibits Peroxynitrite Chemiluminescence}

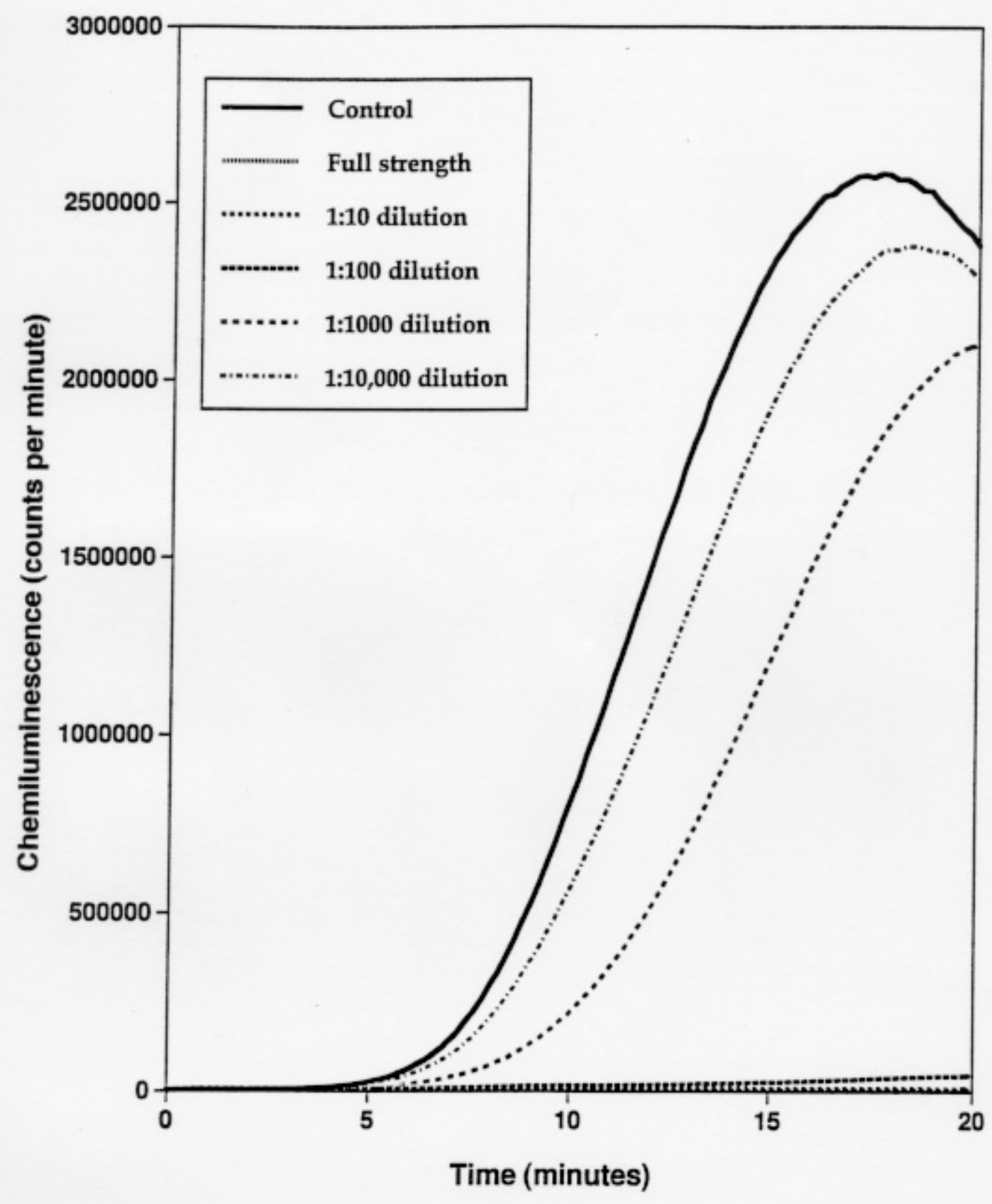


Table 1. Inhibitory effects of different dilutions individual green tea constituents when added to solution with peroxynitrite or SIN-1.

\begin{tabular}{|r|c|c|c|c|}
\hline \multirow{2}{*}{ Dose $\mu \mathrm{M}$} & \multicolumn{2}{|c|}{ Epigallocatechin gallate } & \multicolumn{2}{c|}{$(+/-)$ Racemic Catechin } \\
& SIN-1 & Peroxynitrite & SIN-1 & Peroxynitrite \\
\hline \hline 452 & $100 \pm 1$ & $100 \pm 1$ & $100 \pm 1$ & $100 \pm 1$ \\
\hline 45.2 & $100 \pm 1$ & $99 \pm 1$ & $100 \pm 1$ & $100 \pm 1$ \\
\hline 4.52 & -35 & $90 \pm 10$ & $97 \pm 1$ & $95 \pm 1$ \\
\hline 0.452 & -12 & $25 \pm 4$ & $47 \pm 4$ & $76 \pm 5$ \\
\hline 0.0452 & -10 & $12 \pm 3$ & $2 \pm 3$ & $53 \pm 4$ \\
\hline 0.00452 & $\mathrm{n} / \mathrm{a}$ & $\mathrm{n} / \mathrm{a}$ & -5 & $56 \pm 8$ \\
\hline
\end{tabular}

* Results are expressed as percent inhibition \pm SEM. A negative symbol indicates a stimulation rather than an inhibition.

\begin{tabular}{|c|c|c|c|c|}
\hline \multirow[b]{2}{*}{ Dose $\mu \mathrm{M}$} & \multicolumn{2}{|c|}{ (-) Epicatechin } & \multicolumn{2}{|c|}{ (-) Epicatechin gallate } \\
\hline & $\mathrm{SIN}-1$ & Peroxynitrite & $\mathrm{SIN}-1$ & Peroxynitrite \\
\hline 452 & $100 \pm 1$ & $100 \pm 1$ & $98 \pm 1$ & $100 \pm 1$ \\
\hline 45.2 & $100 \pm 1$ & $100 \pm 1$ & $97 \pm 1$ & $99 \pm 1$ \\
\hline 4.52 & $95 \pm 1$ & $94 \pm 3$ & $84 \pm 2$ & $40 \pm 10$ \\
\hline 0.452 & $47 \pm 4$ & $82 \pm 4$ & $68 \pm 18$ & $44 \pm 8$ \\
\hline 0.0452 & $12 \pm 8$ & $78 \pm 5$ & $n / a$ & $37 \pm 10$ \\
\hline 0.00452 & $n / a$ & $96 \pm 5$ & $\mathrm{n} / \mathrm{a}$ & $27 \pm 1$ \\
\hline
\end{tabular}

* Results are expressed as percent inhibition \pm SEM. A negative symbol indicates a stimulation rather than an inhibition. 


\title{
Study 2
}

\section{Gel Electrophoresis Can Be Used to Assess Oxidative Damage to Plasmid DNA and its Prevention by Green Tea and its Constituents}

\author{
Abstract \\ DNA is found in almost all prokaryotic and eukaryotic organisms, as well as in the \\ mitochondria of eukaryotic organisms. Plasmid DNA is a circular form of double \\ stranded DNA consisting of several thousand base pairs. Due to the extremely large \\ difference in total size, as compared to whole genomic DNA, plasmid DNA has proven to \\ be much easier to separate and measure. Plasmid DNA is generally found as double \\ stranded and supercoiled, however some of the plasmid is found in the relaxed form. \\ Using gel electrophoresis, separating the two forms of plasmid DNA can easily be \\ accomplished. Oxidative insult to the DNA, and other ensuing forms of damage, can be \\ assessed by viewing ethidium-stained DNA separated using an agarose gel. If damage to \\ the DNA does occur, electrophoresis with the gel will separate the different forms of \\ DNA. Native supercoiled DNA runs further from the origin due to its relatively compact \\ size and offers less resistance than relaxed DNA. The linear or relaxed forms, caused by \\ nicking one of the DNA strands, produces less mobility in the gel and thus separates \\ from the native supercoiled form. The key question is: Are green tea-polyphenolic \\ antioxidants effective at preventing such damage to DNA (nicking or mutations)? \\ Green tea is a complex mixture containing several major potent antioxidant constituents \\ e.g., flavins and/or polyphenols. These antioxidants in green tea may react directly or \\ indirectly with strong oxidizers e.g. peroxynitrite or its constituents
}


(superoxide or nitric oxide). These antioxidants (A) can destroy the oxidants. If oxidants attack DNA, (A) could prevent the oxidative damage to DNA. An antioxidant screening system was established with SIN-1 (generator of peroxynitrite) and luminol to produce blue luminescence (See Study 1).

\section{Introduction}

There have been a variety of studies which indicate that peroxynitrite $\left(\mathrm{OONO}^{-}\right)$, a strong oxidizing chemical, causes nicking to plasmids or genomic DNA $(1,2,3)$. Such nicks are thought to be in the sugar-phosphate backbone of the DNA structure (4). In vivo, peroxynitrite has been shown to cause breaks in chromosomal DNA, when cells are treated with it (5). If nicks or even breaks in chromosomal structure were all that occurred to DNA, there are a variety of repair mechanisms which might mend the nick or even the break in the DNA structure and render the original damage to DNA irrelevant. However, if damage is too extensive to the DNA, the repair mechanisms might not reverse the damage. This type of damage has been studied extensively by Szabo and associates (6).

We have been interested in developing a strategy which might be able to prevent the production of peroxynitrite via annihilating one or both of the products which form peroxynitrite namely, the free radicals superoxide and nitric oxide. We developed an assay using a drug (SIN-1) or linsidomine, which generates both necessary radicals $\left(\cdot \mathrm{O}_{2}{ }^{-}\right.$ and $\bullet \mathrm{NO}$ ) in solution, and because of their high affinity for each other, produces peroxynitrite anion or (OONO-) (See Study 1).

The following study produced a rather surprising finding, which is that protection of the attack by precursors of peroxynitrite or peroxynitrite itself are distinctly different 
steps. Tea contains a variety of polyphenolic substances which protect or inhibit the production of peroxynitrite but once the peroxynitrite has been formed these tea polyphenols do not appear protective of DNA even in high doses.

\section{Materials and Methods}

Green Tea and Constituents

Green tea (powdered extract) was purchased from Pharmanex, Simi Valley, CA. 250 mg was dissolved in $10 \mathrm{~mL}$ of phosphate buffered saline (PBS) at $\mathrm{pH}$ at 7.4 and used as a stock solution (dilutions are made using PBS, and antioxidant samples from this original stock solution were diluted every 10 -fold from one to 1 million, i.e., six samples).

The various green tea constituents were purchased from Sigma, St. Louis, MO. The original stock solutions of $10^{-3} \mathrm{M}$ was dissolved in PBS and then diluted as previously mentioned.

Plasmid DNA (used for nicking experiments)

Plasmid DNA was purchased in 10mg per 10mL TBE (1ug plasmid DNA/mL TBE) quantities from Aldevron of Fargo, North Dakota (email address is DNA@aldevron.com). The DNA is supplied as a sterile and buffered solution at a concentration of $1 \mathrm{mg} / \mathrm{ml}$ Tris-EDTA $\mathrm{pH}=8.0$ buffer. The particular plasmid used is termed G-Wiz ${ }^{\mathrm{TM}}$-luciferase high expression plasmid which contains both a kanamycin resistance marker and the luciferase gene. The plasmid uses a cytomegalovirus infectious mechanism and therefore infects both gram negative bacteria, e.g. E coli, as well as mammalian cells. The plasmid has more than 6300 base pairs with a variety of restriction 
enzyme cutting sites available for possible gene insertions and deletions. See figure one for a plasmid gene map displaying only the major genes relevant to this project.

Nicking Plasmid DNA with Peroxynitrite

Plasmid DNA was incubated for 10 minutes at room temperature with various bufferdiluted concentrations of peroxynitrite (P). (P) was purchased from Upstate Biotechnology at Lake Placid, NY. Their e-mail address is techserv@upstatebiotech.com. The original concentration of peroxynitrite is 138mM. The solution contains $0.3 \mathrm{M} \mathrm{NaCl}$ and $0.3 \mathrm{M} \mathrm{NaOH}$.

Peroxynitrite (approx. $50 \mathrm{mmol} / \mathrm{L}$ ) was diluted 1/1000 with water. The original solution was supplied in $0.3 \mathrm{~mol} / \mathrm{L} \mathrm{NaOH}$, and this stabilizes the compound. Once diluted, it must be kept on ice and used quickly, especially after dilution. The diluted basic OONO- is then rapidly injected into the $1 \mathrm{x} \mathrm{TBE}$ buffer at $\mathrm{pH}=7.4$. Under these neutralizing conditions the half-life of OONO- is less than $1 \mathrm{~s}$ (Fig.6). Peroxynitrite is stored at $-80 \mathrm{C}$ until use.

\section{Electrophoresis of Plasmid DNA}

DNA strand breaks in supercoiled DNA were analyzed after agarose gel electrophoresis as described previously (19). The agarose was purchased from Sigma Chemical Co. (St. Louis, MO). Electrophoresis was accomplished using $0.7 \%$ agarose. $1.05 \mathrm{~g}$ of the agarose was measured and dissolved in $150 \mathrm{~mL}$ of $1 \mathrm{x}$ TBE buffer. The solution was then microwaved in a Sanyo conventional microwave oven for ca. $2.5 \mathrm{~min}$. or until all of the agarose had dissolved. The 1x solution of TBE buffer was diluted from 
a 10x solution of TBE buffer that was prepared by thoroughly mixing $54 \mathrm{~g}$ Tris, $27.5 \mathrm{~g}$

Boric Acid, and 2mL 0.5M EDTA $\mathrm{pH}=8.0$. Deionized water was added to raise the total volume to $500 \mathrm{~mL}$.

The first gels were run in order to determine the necessary amount of plasmid DNA. Volumes of $2 u \mathrm{~L}, 5 u \mathrm{~L}, 10 u \mathrm{~L}, 15 u \mathrm{~L}, 20 u \mathrm{~L}, 30 u \mathrm{~L}, 40 u \mathrm{~L}$, and $50 u \mathrm{~L}$ of the original $1 \mathrm{mg} / \mathrm{mL}$ plasmid solution were loaded into the gels with $3 u \mathrm{~L}$ of loading buffer. From Fig. 1 it was determined that a volume of $2 u \mathrm{~L}$ of plasmid sufficiently showed a high percentage of the plasmid in the supercoiled as opposed to a smaller percentage in the nicked form.

A dose response with peroxynitrite was then done with the agarose gels to determine the proper dosage and length of incubation. Peroxynitrite was diluted with TBE buffer in a range of $2: 1$ to $4: 1$ (see starting concentrations of peroxynitrite above). $50 u \mathrm{~L}$ of the various dilutions of peroxynitrite were added to the solutions of plasmid DNA with TBE buffer and loading buffer and electrophoresed and placed in an incubator for $0.5 \mathrm{~h}-1 \mathrm{~h}$. From Fig. 2 it was determined that a 2:1 dilution of peroxynitrite was a sufficient dose to cause the highest percentage of the plasmid DNA to be in the nicked form.

To determine whether or not antioxidants are able to protect the plasmid DNA from the oxidative damage caused by peroxynitrite, green tea and/or its constituents were incubated with the solution mix at doses ranging from full strength $\left(10^{-3} \mathrm{M}\right)$ to $1: 100$ of that original stock.

The electrophoresis was carried out for $1.5 \mathrm{~h}$ at $50 \mathrm{mV}$. After electrophoresis, the gels were then stained with ethidium bromide solution $\left(700 \mathrm{~mL}_{\mathrm{d}} \mathrm{H}_{2} \mathrm{O}+70 u \mathrm{~L} \mathrm{EtBr} 10 \mathrm{mg} / \mathrm{mL}\right)$ for approximately $15 \mathrm{~min}$. The DNA was viewed under ultraviolet light $(302 \mathrm{~nm})$ to cause the ethidium-stained DNA to fluoresce orange. The nicked plasmid is retarded in its 
movement due to oxidative damage and runs a shorter distance from the origin than the native supercoiled DNA form of the plasmid. Aldevron states that less than $5 \%$ of the plasmid is supplied in the relaxed or nicked form.

\section{Statistics}

Using the FluoroChem imaging device for stained plasmid DNA we quantitated fluorescent spots with the ultraviolet box set $(302 \mathrm{~nm})$ on ethidium settings for the agarose gels using AlphaEase ${ }^{\mathrm{TM}}$ software 2D densitometry. The instrumentation is available from the Alpha Innotech Corporation, San Leandro, CA. The densitometry was done using the software and $\%$ protection calculated by comparing the density of the ethidium based fluorescent signal from the nicked DNA to the density of the signal from the unnicked plasmid DNA designated as $100 \%$. Therefore, if a given peroxynitrite concentration nicked the DNA and produced $80 \%$ nicking, this would be subtracted from the $100 \%$ to give $20 \%$ nonnicked DNA. If the presence of the green tea and/or its constituents produced $90 \%$ non-nicked DNA this would be $87 \%$ protection because you would divide $7 / 8 \times 100$ and get $13 \%$ damage. 


\section{Results}

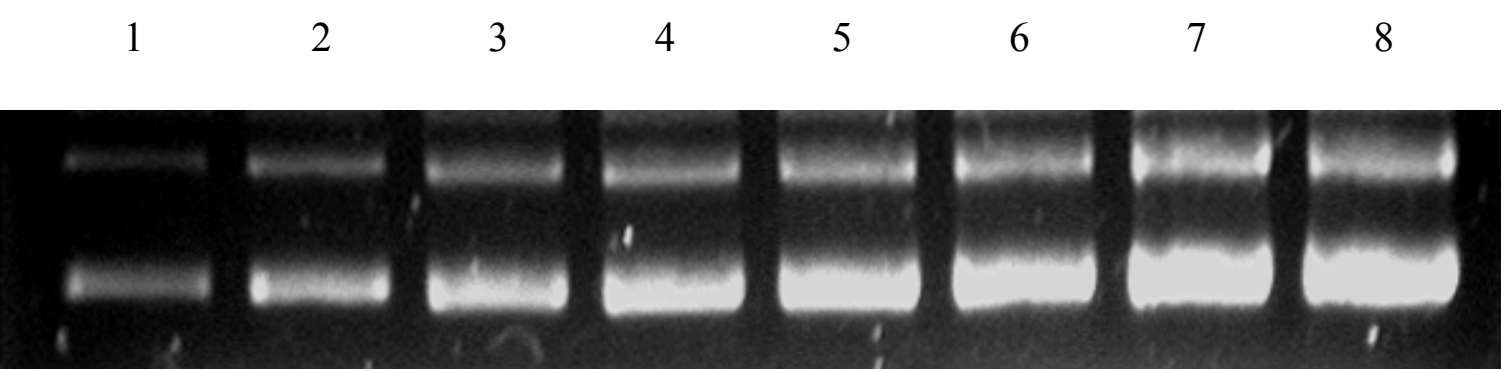

Figure 1: Represents the attempt to find the best concentration of plasmid DNA. Lanes $1-8$ represent concentrations of $2 u \mathrm{~L}, 5 u \mathrm{~L}, 10 u \mathrm{~L}, 15 u \mathrm{~L}, 20 u \mathrm{~L}, 30 u \mathrm{~L}, 40 u \mathrm{~L}$, and $50 u \mathrm{~L}$ of $1 u \mathrm{~g} / u \mathrm{~L}$ DNA, respectively. Although as Table 1 indicates, there is greater differences when comparing percentages of the amount of supercoiled to nicked, the amount of $2 u \mathrm{~L}$ of plasmid was chosen due to the fact that it showed the least amount of DNA in the nicked form.

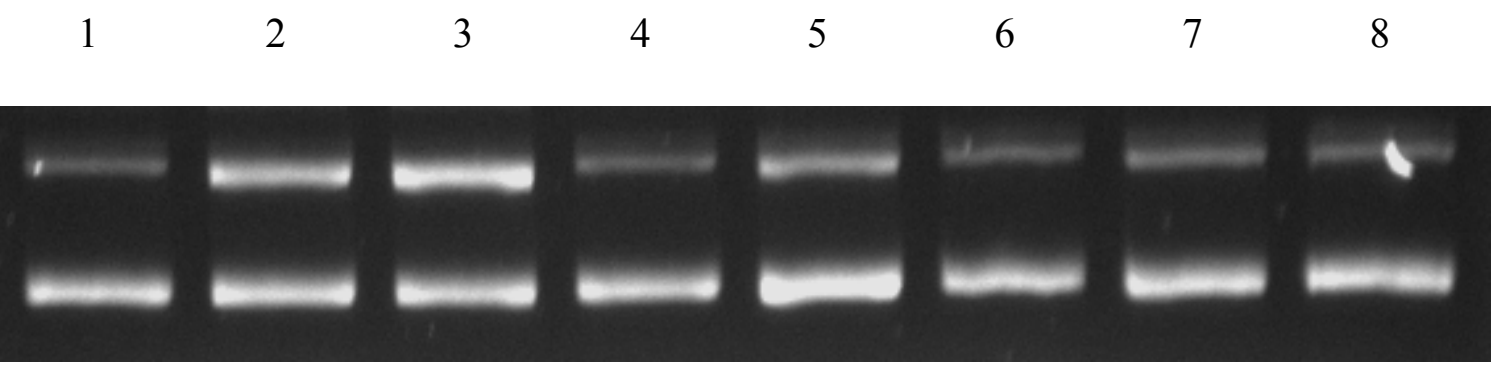

Figure 2: Represents the attempt to find the best concentration of peroxynitrite, along with ample incubation period. Lane 1 and 8 represents plasmid DNA alone, while lanes 2-7 represent peroxynitrite diluted 2:1 and incubated for $0.5 \mathrm{~h}-1 \mathrm{~h}$ for lanes 2 and 3 , peroxynitrite diluted 3:1 and incubated for $0.5 \mathrm{~h}-1 \mathrm{~h}$ for lanes 4 and 5, and peroxynitrite diluted 4:1 and incubated for $0.5 \mathrm{~h}-1 \mathrm{~h}$ for lanes 6 and 7. 


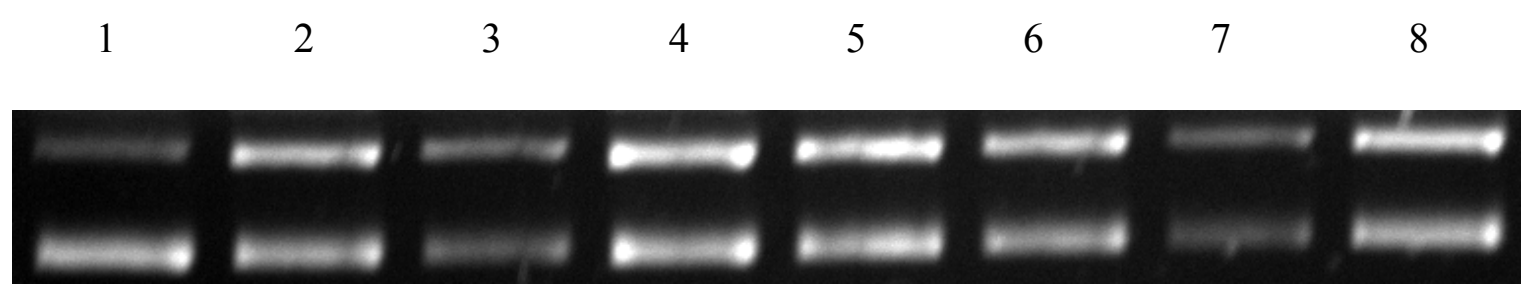

Figure 3: Represents an attempt at protection by various dilutions of green tea constituent polyphenols. Lane 1 represents plasmid DNA alone. Lane 2 represents plasmid DNA with peroxynitrite. Lanes 3-5 represent plasmid DNA incubated with peroxynitrite and (-) epicatechin beginning with full strength and diluted to 1:100 (see starting concentrations of various green tea constituent polyphenols above). Lanes 6-8 represent plasmid DNA incubated with peroxynitrite and (-) epigallocatechin gallate beginning with full strength and diluted to $1: 100$. 


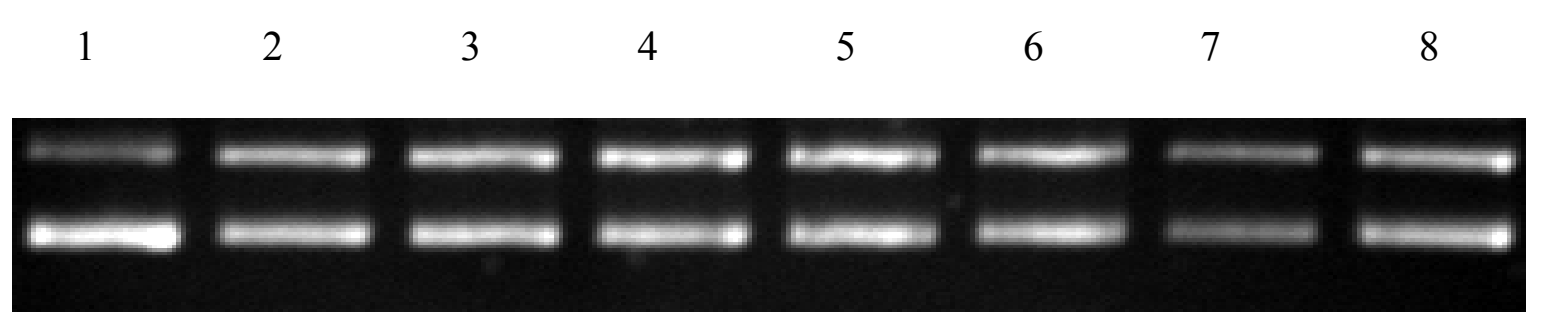

Figure 4: Represents an attempt at protection by green tea extract along with an additional polyphenolic constituent. Lane 1 represents plasmid DNA alone. Lane 2 represents plasmid DNA with peroxynitrite. Lanes 3-5 represent plasmid DNA incubated with peroxynitrite and green tea extract (see initial concentrations above) beginning with full strength and diluted to 1:100. Lanes 6-8 represent plasmid DNA incubated with peroxynitrite and catechin beginning with full strength and diluted to 1:100 (see starting concentrations of various green tea constituent polyphenols above). 
Table 1: The amount of protection of plasmid DNA (or increased damage) from different dilutions of green tea extract and several of its constituents when incubated with peroxynitrite.

\section{Percent Protection}

Green Tea Extract

Dose $(u \mathrm{~mol} / \mathrm{L})$

$(+)$ Catechin

\begin{tabular}{|c|c|c|c|}
\multicolumn{1}{c}{ Dose $(u \mathrm{~mol} / \mathrm{L})$} & $\%$ & Dose $(u \mathrm{~mol} / \mathrm{L})$ & $\%$ \\
\hline Full Strength $(452)$ & 8.3 & Full Strength $(452)$ & 14.7 \\
\hline $1: 10(45.2)$ & 0 & $1: 10(45.2)$ & 51.5 \\
\hline $1: 100(4.52)$ & 0 & $1: 100(4.52)$ & 17.6 \\
\hline
\end{tabular}

\section{Percent Protection}

(-) Epicatechin $\quad(-)$ Epigallocatechin gallate

Dose $(u \mathrm{~mol} / \mathrm{L})$

$\% \quad$ Dose $(u \mathrm{~mol} / \mathrm{L})$

\begin{tabular}{|c|c|c|c|}
\hline Full Strength (452) & 44.1 & Full Strength (452) & 1.5 \\
\hline $1: 10(45.2)$ & $-30.9^{*}$ & $1: 10(45.2)$ & 53.0 \\
\hline $1: 100(4.52)$ & $-22.0^{*}$ & $1: 100(4.52)$ & $-17.6^{*}$ \\
\hline
\end{tabular}

Results are expressed as percent protection. * A negative symbol indicates an actual increase in the amount of nicked plasmid DNA and therefore, more damage than the control set by optimum dose of peroxynitrite found for this study. 


\section{Discussion}

It can be deduced that there are multiple levels of antioxidative protection. First, antioxidants can destroy the pieces of peroxynitrite $\left(\cdot \mathrm{O}_{2}\right.$ and $\left.\bullet \mathrm{NO}\right)$, protect from peroxynitrite itself, or protect from the damage caused to DNA by peroxynitrite.

The results shown in figures 3 and 4 indicate that green tea extract and the polyphenolic constituents listed are at best only slightly protective, if protective at all. $(+)$ Catechin showed the greatest amount of protection throughout the various doses, while green tea extract itself seemed to be the least protective. Perhaps the reasoning for which the extract seemed to be the least protective lies in the fact that there is a multitude of compounds found in the extract. There is a scale of oxidation (ox) and antioxidation (Aox) in which the strongest oxidant would be at one end of the scale with the strongest antioxidant at the other $(\mathrm{Ox}$ Aox). A given substance could be an oxidant or an antioxidant depending on its relative placement on this scale. For example, Vitamin C (ascorbic acid) could be an oxidant or an antioxidant, depending on with what it would be compared or with what it would be reacted. This would also explain why you see an actual stimulation in the levels of DNA damage in several instances. Another possible reason that green tea extract and its polyphenolic constituents did not appear to be that effective in preventing DNA damage and mutations could be explained by the aforementioned study by Szabo and associates regarding the extent of actual damage (6). It is possible that peroxynitrite, being the powerful oxidizer it is and capable of causing mutations at a multitude of levels itself, could have caused damage to the DNA past the point of repair. 
Peroxynitrite causes damage to DNA other than nicking. MIT researchers demonstrated that peroxynitrite oxidizes or nitrates guanines producing 8-oxoguanines or 8-nitroguanine (10). Furthermore, they showed that consecutive guanines are readily attacked but certain isolated guanines were oxidized or nitrated even more readily, creating mutational hot spots. A mutational hot spot can be defined as the genetic entity most mathematically likely to produce a mutation. Therefore, the main effects of peroxynitrite are to nick the DNA backbone or oxidize or nitrate the guanines or all of these. To summarize there are three levels of complexity at which antioxidant/cellular repair mechanisms might occur. First, the antioxidants could prevent the precursors of peroxynitrite (superoxide and nitric oxide) from being generated or from getting together to form peroxynitrite. Secondly, antioxidants could interact once peroxynitrite is formed. An example of this would be the effect of uric acid which reacts with peroxynitrite and forms a variety of compounds including allantoin and a nitrated imidazole (11). This type of annihilation reaction with an antioxidant could prevent DNA from being damaged or mutated by peroxynitrite. This might include both genomic and mitochondrial DNA. Thirdly, if the DNA was not damaged too much, a cell's repair mechanisms might repair the minimal damage and the DNA might remain intact, and in the case of plasmids, DNA might become infective under the conditions used in our study.

Matsumoto et al (12) have recently demonstrated that Nth DNA glycosylase is involved with the removal of 8-oxoguanines/guanine mispairs in DNA (12). This would probably be the enzyme used by E coli to repair peroxynitrite mediated DNA damage. This might include 8-nitroguanine which would likely be repaired by the same DNA glycosylase. 
In addition, we thought that these same compounds would be useful in preventing the damage to DNA caused by peroxynitrite itself or even with other strong oxidants such as hypochlorite. We needed an assay which would produce a simple but useful endpoint in determining whether DNA could be repaired or whether the damage to DNA was too extensive that repair was not possible. Other research from our laboratory demonstrated that if the luciferase plasmid is not too extensively damaged by peroxynitrite, when placed in solution with permissive E coli, the luciferase will be expressed. Green tea or its polyphenols could not prevent extensive damage and the luciferase gene was inactive. However, berry extracts, e.g. blueberry, did prevent luciferase plasmid DNA expression and the luciferase gene was expressed. Therefore, some fruit extracts prevent the peroxynitrite damage to the luciferase plasmid, so the E coli repair mechanisms were effective (publication in progress). This can only happen if the plasmid DNA is not extensively damaged or if damaged slightly and can be repaired by the bacterial repair mechanisms. The idea is that maybe we could use a simple nutritional extract to prevent dangerous mutations which could persist without repair.

The take home message of all this is that antioxidants have the possibility to protect on a multitude of levels. The larger the variety of antioxidants available, the better are your chances for protection against mutation. Studies are now indicating the levels of damage (mutations) caused by oxidants throughout a lifetime are measurable in urine (13). As a person ages, the damage to DNA increases. This evidence indicates that a variety of different antioxidants are needed for a more complete protection from 
mutations caused by oxidation. It is clear that protection from oxidative based mutation should occur early in life and continue in order to live a life free of oxidative disease. 


\section{References:}

1. Ohshima H, Yoshie Y, Auriol S and Gilbert I. Antioxidant and Prooxidant action of flavonoids: Effects on DNA damage induced by nitric oxide, peroxynitrite, and nitrosyl anion. Free Radical. Biol Med 1998; 25 (9): 1057-65.

2. Salgo MG, Stone K, Squadrito GL, Battista JR, and Pryor WA. Peroxynitrite causes nicks in plasmid pBR322. Biochem Biophys Res Comm 1995; 210: 1025-30.

3. La Marr MA, Sandman KM, Reeve J, and Dedon PC. Differential effects of DNA supercoiling on radical-mediated DNA strand breaks. Chem Res Toxicol 1997;10: 11181122.

4. Yoshie Y, Ohshima H. Synergistic induction of DNA strand breakage caused by nitric oxide with catecholamines: Implications for neurodegenerative disease. Chem Res Toxicol 1997; 10 (9): 1015-22.

5. Sies $\mathrm{H}$ and deGroot H. Role of Reactive Oxygen Species in Cell Toxicity. Toxicol Letters 1992; (64-65): 547-51.

6. Virag L, Scott GS, Awtal-Szalmas P, O'Connor M, Okashima H, and Szabo C. Requirement of intracellular calcium mobilization for peroxynitrite-induced poly (ADPribose) synthase activation and cytotoxicity. Molecular Pharm 1999; 56 (4): 824-33.

7. Yermilov V, Yoshie Y, Rubio J, and Ohshima H. Effects of carbon dioxide/bicarbonate on induction of DNA single strand breaks caused by peroxynitrite. FEBS Letters 1996; 399: 67-70.

8. Van Dyke K, McConnell P, and Marquardt L. Green Tea Extract and its polyphenols markedly inhibit luminol-dependent chemiluminescence activated by peroxynitrite or SIN-1. Luminescence 2000; 15: 37-43.

9. Van Dyke K, Ogle CL, and Reasor MJ. Antioxidant activity in grape and other fruit extracts inhibits peroxynitrite-dependent oxidation (from SIN-1) as measured by luminescence. Luminescence Biotechnology, CRC Press 2001 (in press).

10. Tretyakova NY, Barney S, Wishnok JS, Wogan GN, and Tannerbaum SR. Peroxynitrite-induced DNA damage in the Sup F gene: correlation with mutational spectrum. Mutation Research 2000; 447: 287-303.

11. Santos CX, Anjos EI, and Augusto O. Uric acid oxidation by peroxynitrite: multiple reactions, free radical formation, and amplification of lipid oxidation. Arch Biochem, Biophys 1999; 372 (2): 285-94. 
12. Matsumoto Y, Zhang QM, Takao M, Yasui A, and Yonei S. E. coli $\mathrm{N}^{\text {th }}$ and human $\mathrm{hN}^{\text {th }}$-1 DNA glycosylase are involved in removal of 8-oxoguanosine from 8-

oxoguanosine/guanine misrepair in DNA. Nucleic Acid Research 2001; 29 (9): 1975-81.

13. Helbock HJ, Beckman KB, Shigenaga MK, Walter PB, Woodall AA, Yeo HC, and Ames BN. DNA oxidation matters: The HPLC-electrochemical detection assay of 8oxo-deoxyguanosine and 8-oxo-guanine. Proc Natl Acad Sci 1998; 95: 288-93. 